\title{
A Bird's Eye Survey of Central American Planorbid Molluscs
}

\author{
W Lobato Paraense
}

Departamento de Malacologia, Instituto Oswaldo Cruz-Fiocruz, Av. Brasil 4365, 21045-900 Rio de Janeiro, RJ, Brasil

In the course of two trips to Central America (June 1967 and July-August 1976) I had the opportunity of collecting topotypic specimens of Planorbis nicaraguanus Morelet, 1849, anatomically defined in this paper, and of P. yzabalensis Crosse \& Fischer, 1879, the identity of the latter with Drepanotrema anatinum (Orbigny, 1835) is confirmed. The following planorbid species were also found: Helisoma trivolvis (Say, 1817) in Nicaragua, Guatemala, Costa Rica and Belize; H. duryi (Wetherby, 1879) in Costa Rica; Biomphalaria helophila (Orbigny, 1835) in Guatemala, Belize, Nicaragua, Costa Rica and El Salvador; B. kuhniana (Clessin, 1883) in Panama; B. obstructa (Morelet,1849) in Guatemala, Belize and El Salvador; B. straminea (Dunker, 1848) in Costa Rica; B. subprona (Martens, 1899) in Guatemala; D. anatinum (Orbigny,1835) in Belize, Guatemala, Nicaragua and Costa Rica; D. depressissimum (Moricand,1839) in Nicaragua, Costa Rica and Panama; D. lucidum (Pfeiffer, 1839) in Guatemala, Belize and Nicaragua; D. surinamense (Clessin, 1884) in Costa Rica and Panama; and Gyraulus percarinatus sp. $n$. in Panama.

The occurrence of $\mathrm{B}$. kuhniana and $\mathrm{D}$. surinamense is first recorded in Central America, and Gyraulus percarinatus is the first representative of the genus provenly occurring in the American continent south of the United States.

The following synonymy is proposed: Planorbis declivis Tate, $1870=$ Biomphalaria helophila (Orbigny, 1835); Planorbis isthmicus Pilsbry, 1920 = Biomphalaria kuhniana (Clessin, 1883); Planorbis cannarum Morelet, 1849 and Segmentina donbilli Tristram, 1861 = Biomphalaria obstructa (Morelet, 1849); and Planorbis yzabalensis Crosse \& Fischer, 1879 = Drepanotrema anatinum (Orbigny, 1835), confirming Aguayo (1933).

Key words: Helisoma duryi - H. trivolvis - Biomphalaria helophila - B. kuhniana - B. nicaraguana - B.obstructa - B. straminea B. subprona - Drepanotrema anatinum - D. depressissimum - D. lucidum - D. surinamense - Gyraulus percarinatus - Belize Costa Rica - El Salvador - Guatemala - Nicaragua - Panama - synonymy

The present paper is intended to contribute to the knowledge of the distribution of Central American Planorbidae. It deals with samples taken during collecting trips to the countries of the region, except Honduras.

The zoogeographic importance of Central America as a filter bridge and sweepstakes route is widely recognized (e.g., Simpson 1953). Accordingly, a better knowledge of its planorbids (associated, when possible, with data from the fossil record) is essential for investigating the origin of the mixture that has come to make up the Neotropical planorbid fauna.

As noted by Harry (1962), over 250 species of planorbid snails were named from the Neotropics between 1798 and 1957; and until three decades ago the systematics of the Neotropical planorbids was "still in a chaotic state" (Malek 1969). Undoubtedly appreciable progress has been made thenceforth,to which we have contributed with studies involving topotypes of 106 nominal species, 23 of which are considered valid.

\section{METHODS}

The snails were collected with a strainer $14 \mathrm{~cm}$ in diameter and $7 \mathrm{~cm}$ deep, with a 16 mesh wire net. Since at that time we used no relaxing agents, the following protocol was followed. A specimen freely moving about, with the head and foot well exposed, is carefully picked up

Fax +55-21-2280.5840. E-mail: paraense@ioc.fiocruz.br Received 7 August 2002

Accepted 12 September 2002 with a forceps, so as to prevent it from retracting back to the shell. The shell aperture is kept upward, and the snail is gradually plunged into hot water at about $70^{\circ} \mathrm{C}$ for a time proportional to the animal's size (approximately 45 sec for snails about $20 \mathrm{~mm}$ in shell diameter). If the shell is plunged to the level of the aperture for the first $15 \mathrm{sec}$, the animal usually will not retract and then, after being completely submerged, will die. Care must be taken not to exceed the suitable temperature and time of immersion, since blood and tissue cooking would hinder dissection. The dead animal is plunged into cold water and gently pulled by the head-foot with a small forceps, so as to disconnect the insertion of the columellar muscle. The whole animal is then drawn out of the shell, which remains unbroken and filled with water which dilutes the blood residuum avoiding its putrefaction within the shell. The animal is fixed in slightly modified Railliet-Henry's fluid (distilled water $930 \mathrm{ml}$, sodium chloride $6 \mathrm{~g}$, formalin $50 \mathrm{ml}$, glacial acetic acid $20 \mathrm{ml}$ ), where it must remain for at least $24 \mathrm{~h}$ before dissection. One change of the fixative after the first $24 \mathrm{~h}$ is advisable. The amount of fluid should be not less than 10 times the volume of material to be fixed. In specimens with lamellate shell, and in most species of Drepanotrema, the animal is easily broken when attempts are made to pull it from the shell. In such cases the whole specimen (animal within the shell) should be placed in the fixative after immersion in hot water for about $15 \mathrm{sec}$; owing to $\mathrm{CO}_{2}$ production, the fixative should be changed several times to avoid unstopping of the vial under gas pressure. The radulae are separated from the buccal mass by digestion in a vial with $10 \% \mathrm{NaOH}$ (left overnight in the incubator at $56^{\circ} \mathrm{C}$ ). They are then rinsed 
in tap water. Those of Biomphalaria nicaraguana were mounted in a drop of glycerin on a microscopic slide, with the dorsal (toothed) surface upwards as in the living animal; and those of Gyraulus percarinatus (as well as its shells) were sputtered with gold to be observed with a Zeiss electron microscope (model DSM-940). Measurements were made on camera lucida drawings.

Voucher specimens were deposited in the Malacological Collection of the Oswaldo Cruz Institute (CMIOC).
Genus Helisoma Swainson, 1840

Helisoma trivolvis (Say, 1817)

(Fig. 1)

Twenty-nine specimens from a pool by the margin of Lake Nicaragua at Granada, Granada Department, 9 August 1976 (CMIOC-2318), together with Biomphalaria obstructa and Drepanotrema lucidum. Largest shell: diameter $19 \mathrm{~mm}$, width $7 \mathrm{~mm}$ at aperture $(5.5 \mathrm{~mm}$ at begin-
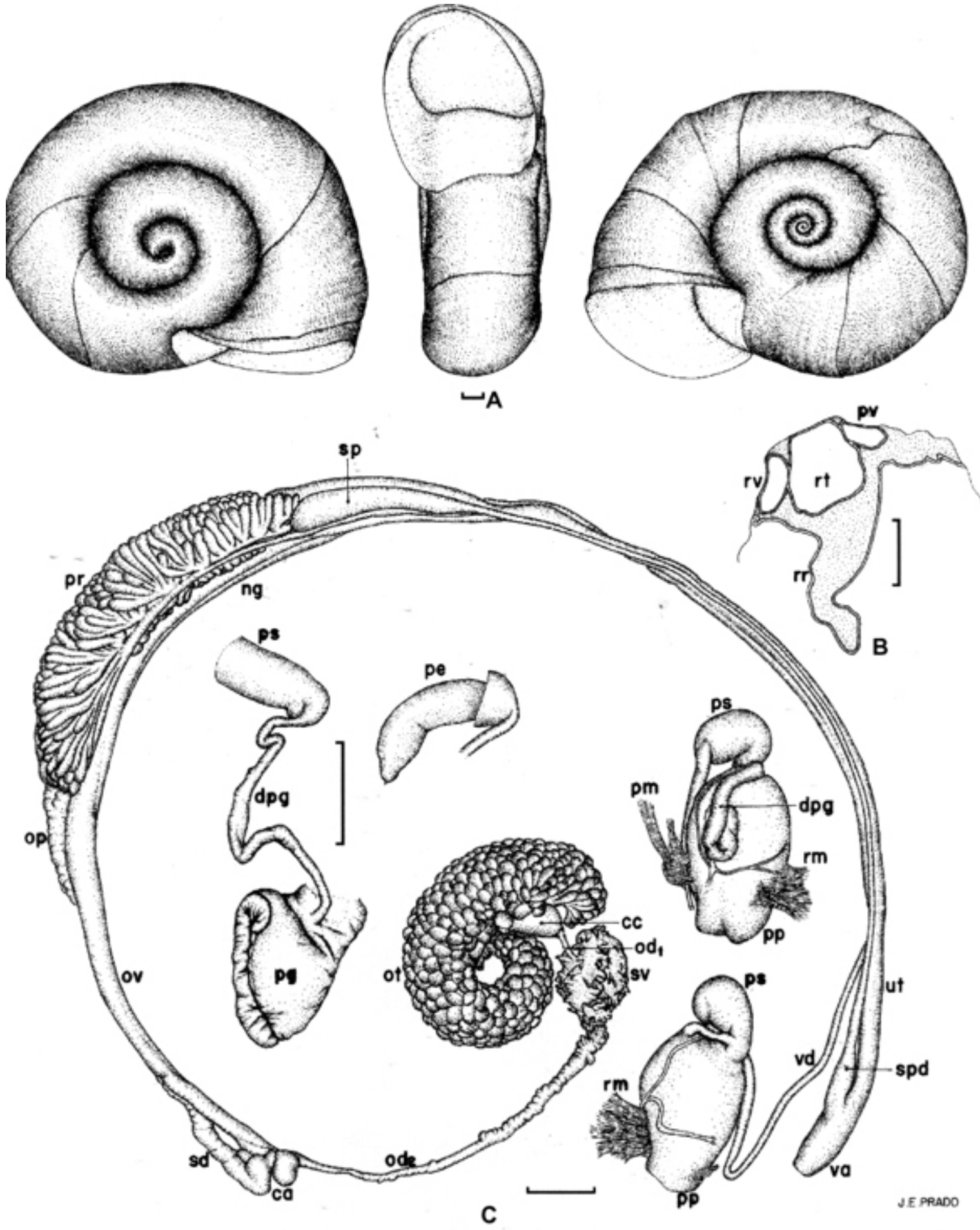

Fig. 1: Helisoma trivolvis from Granada, Nicaragua - A: shell; B: renal region, cross-section; C: reproductive system. Bar $=1 \mathrm{~mm}$ 
ning of outer whorl), whorls 5.75. For description, see Paraense (1976b: 188).

Additional specimens of $H$. trivolvis were collected from Lake San Cristóbal (or Petencito), near Cobán, Alta Verapaz Department, Guatemala, 5 August 1976, largest shell $16.5 \mathrm{~mm}$ diameter (CMIOC-2317); from Coris river, Cartago Province, Costa Rica, 12 August 1976, largest shell $14 \mathrm{~mm}$ (CMIOC-2336); and from a pond at Boston village, Belize District, 30 July 1976, largest shell $15 \mathrm{~mm}$ (CMIOC-2298).

In Tate's (1870) paper on the Nicaraguan molluscs this species is called Planorbis tumidus Pfeiffer, 1839, as a dweller of Lake Nicaragua and San Juan river. Pfeiffer's original "description" (1839:354) merely says: "Specimina incompleta, $\mathrm{Pl}$. fragili affinia", so that $P$. tumidus must be considered a nomen nudum. Moreover, similarity to $P$. fragilis cannot be determined since, in Martens' (1899: 389) words, "P.tumidus, L. Pfeiffer (1839), also undefined, is said to resemble $P$. fragilis, a species undescribed at that time." Really, the first published description and figures of $P$. fragilis were given by Dunker (1850: 46-47, Pl. 10, Figs. 41-43), and referred to a Mexican Helisoma.

In spite of the indefinition of P. tumidus Pfeiffer, subsequent authors treated this name as valid. Dunker (1850: 39-40) described its shell as having 9 lines $(19 \mathrm{~mm})$ in diameter and 3 lines $(6.3 \mathrm{~mm})$ in width at the aperture, and compared young specimens to a flat variety of $P$. trivolvis Say. Strebel (1874: 40-42) gave a detailed description of shells regarded by him as $P$. tumidus Pfeiffer, collected together with $P$. trivolvis at Veracruz, Mexico, and figured one specimen from Cuba considering it very closely related to trivolvis. If the International Code is to be followed, $P$. tumidus Pfeiffer 1839 is not an available name and must be replaced by P. tumidus Dunker, 1850 .

\section{Helisoma duryi (Wetherby, 1879)}

Fifteen specimens from Coris, Costa Rica, were received from Dr Rodrigo Zeledón (INCIENSA) in August 1981 (CMIOC-2720); largest shell: diameter $15 \mathrm{~mm}$, width $9 \mathrm{~mm}$ at aperture (5.5 at beginning of outer whorl), whorls 5. In shell and anatomic characters they are indistinguishable from the specimens studied by Paraense (1976a).

Genus Biomphalaria Preston, 1910

Biomphalaria helophila (Orbigny, 1835) (Fig. 2)

Ten specimens from a marsh at El Prado, Izabal Department, Guatemala, 4 August 1976 (CMIOC-2312), together with Drepanotrema anatinum. Largest shell: diameter $5 \mathrm{~mm}$, width $1.5 \mathrm{~mm}$ at aperture and at beginning of outer whorl, whorls 4.5. In shell and anatomic characters they are indistinguishable from topotypic specimens from Peru studied by Paraense (1996a), who also collected this species in Belize, Nicaragua and Costa Rica (Paraense 1996a). As shown by Paraense (1996a), Planorbis dentiens Morelet, 1849 from Belize, and Tropicorbis shimeki F.C. Baker, 1945 from Ometepe, Nicaragua, are synonyms of B. helophila.

After publishing those findings I realized that $B$. helophila also occurs at Acoyapa, Chontales Department,
Nicaragua, 9 August 1976 (CMIOC-2322A), sharing a swamp with $B$. nicaraguana and $D$. depressissimum, to be dealt with below.

B. helophila was collected by Dr R Milward de Andrade from Lake Coatepeque, El Salvador, April 1963 (CMIOC-757), 17 specimens. Largest shell: diameter 5.5 $\mathrm{mm}$, width $2 \mathrm{~mm}$ at aperture $(1.5 \mathrm{~mm}$ at beginning of outer whorl), whorls 4.5 , lamellate.

$B$. helophila was studied by Tate (1870: 159 , no figure) under the name of P. declivis, as follows:

35. Planorbis declivis, Tate. Shell orbicular, depressed, light horn colored, somewhat shining, strongly and regularly wrinkled across; whorls four to five, rounded, suture deep, the last two whorls flat above and below, concealing the others; the spire and umbilicus deeply and abruptly impressed; last whorl suddenly deflected at the aperture, which is horizontal and nearly circular; peristome united all round; outer lip slightly reflected.

Dimensions of adult shell: greater diameter .25 inch [6.3 $\mathrm{mm}]$; height .075 inch [1.9mm].

Marshy pools San Augustin near Acoyapa,living in company with Planorbis kermatoides and Velletia excentrica.

Tate's description applies well to Orbigny's syntypes (in Paraense 1996a, Fig. 1).

FC Baker (1945: 85) placed $P$. declivis in the genus Tropicorbis Brown \& Pilsbry, 1914, subgenus Obstructio Haas, 1939, the latter characterized by the presence of apertural lamellae during some stage of growth of the shell. He also figured (Plate 133, Figs 25-27) a Nicaraguan shell from the collection of the US National Museum (no. 24006), closely resembling our specimen of Fig. 2A. Four years before (Baker 1941) he had proposed the new name Tropicorbis tatei for $P$. declivis, as the latter was preoccupied by $P$. declivis Braun, a fossil planorbid from Germany mentioned by Genth (1848). This nomenclatural change was overlooked by the editor of his posthumous monograph on the family Planorbidae.

Other homonyms are Planorbis declivis Sowerby (1877, Pl. 4, Fig. 29) and P. declivis "Gould" Clessin (1884: 142, pl. 17, Fig. 13). The former, from unknown locality, about $14 \mathrm{~mm}$ in diameter and $5 \mathrm{~mm}$ in width at the aperture, is a wider shell resembling Helisoma. The latter, from Cuba, 5 by $1 \mathrm{~mm}$ in the description but $3.5 \mathrm{~mm}$ in the figure, seems to represent a young specimen of $D$. lucidum (Pfeiffer, 1839).

\section{Biomphalaria kuhniana (Clessin, 1883)}

(Fig. 3)

Thirty specimens from a "Chinese well" in a farm at La Isleta (environs of Panama City), 11 June 1967 (CMIOC-1637). Largest shell: diameter $8.5 \mathrm{~mm}$, width 3 $\mathrm{mm}$ at aperture ( $2.5 \mathrm{~mm}$ at beginning of outer whorl), whorls 4.75. In shell and anatomic characters they are indistinguishable from topotypes from Paramaribo (Surinam) studied by Paraense (1988).

Additional specimens of B. kuhniana were collected, on the same day, at other localities near Panama City: swamps at Las Cumbres, largest shell 7mm (CMIOC-1635); drainage ditches near the hippodrome, largest shell $8 \mathrm{~mm}$ (CMIOC-1639); and at the grounds of the National University, Tocumen, largest shell 8 mm (CMIOC-1642). 
The shell of this snail is similar to that of $P$. isthmicus Pilsbry, 1920, collected from so called "Chinese wells" at Panama City, and here considered a junior synonym of $B$. kuhniana.

Biomphalaria nicaraguana (Morelet, 1851) (Fig. 4)

Fifty-six specimens from a swamp at Acoyapa (Chontales Department), near Lake Nicaragua, 9 August 1976 (CMIOC-2322), together with B. helophila and D. depressissimum. Largest shell: diameter $10 \mathrm{~mm}$, width $3 \mathrm{~mm}$ at aperture (2.5 $\mathrm{mm}$ at beginning of outer whorl), whorls 5.25 (Fig. 4B). Reviewing the descriptions of Neotropical planorbids I identified these specimens, by the shell characters, with Planorbis nicaraguanus, originally described by Morelet (1851: 14, no figure, type locality Lake Nicaragua):
112. Pl. nicaraguanus.

T. discoidea, depressa, obtuse angulata, tenuis, confertissime striatula, rufo-cornea, nitens, utrinque concava; anfr. 6 sensim crescentes, sutura profunda discreti; apertura obliqua, lunato-subangularis. Labrum simplex, tenue.

Diam. 16. - Altit. 5.

H. lacum Nicaraguanensem.

The type of $P$. nicaraguanus is shown in Fig. 4A; although larger than the specimen of Fig. 4B, the likeness between them becomes evident on the drawing.

Smaller shells of our specimens are light horn in color and barely translucent, but owing to adsorption of environmental material the shell grows dark to become black in full-grown specimens. The growth lines are moderately marked. The whorls, delimited by deep sutures, increase regularly in width and are roundly protuberant on both sides, more on the left. The inner whorl is deep sunken on
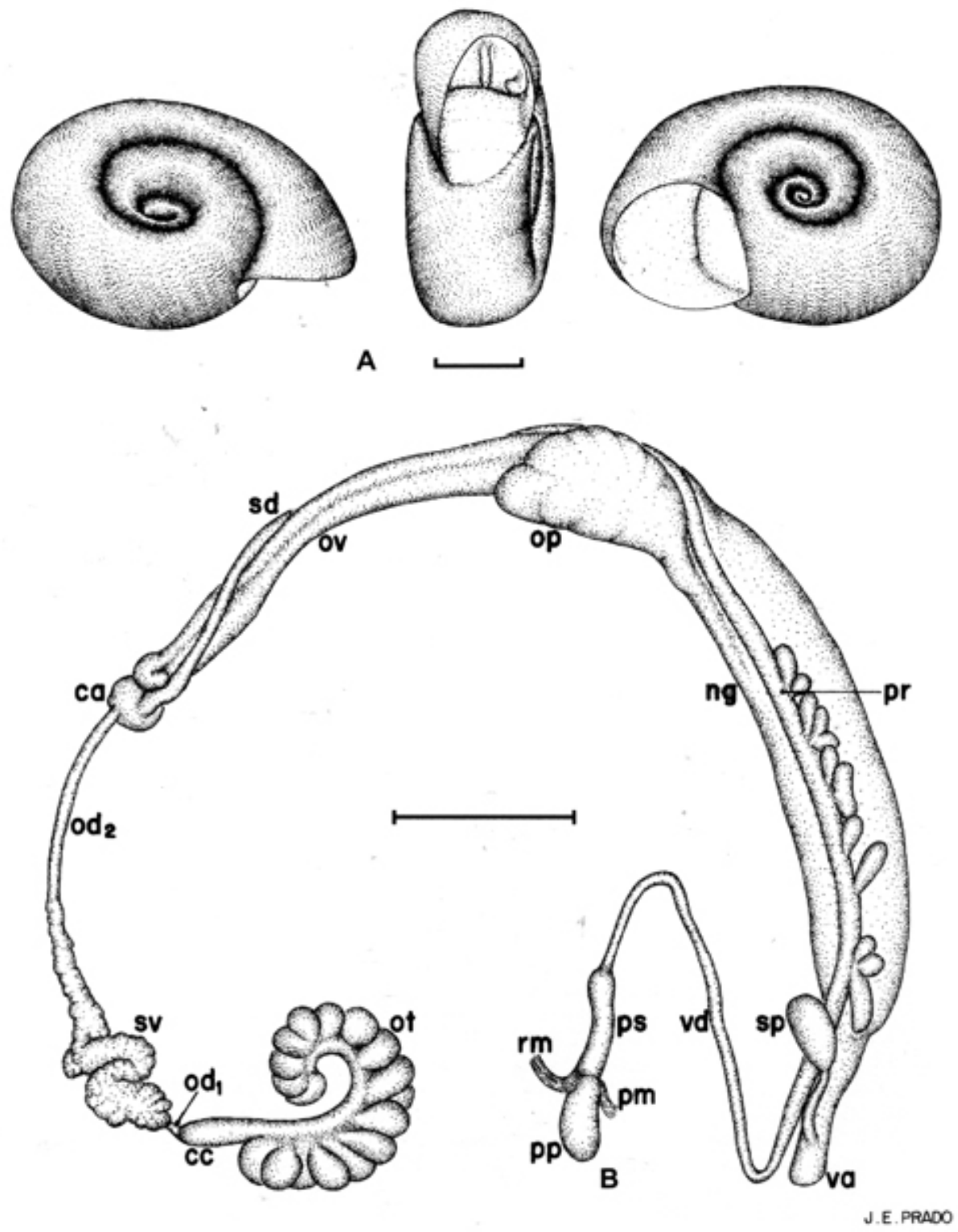

Fig. 2: Biomphalaria helophila from El Prado, Guatemala - A: shell; B: reproductive system. Bar $=1 \mathrm{~mm}$ 
the right side and less so on the left, where it is more clearly visible. The periphery is rounded and somewhat shifted rightward.The aperture is roundish, with a sharp peristome and a white callus on the parietal wall. There are no apertural lamellae.

The cephalopedal mass is diffusely brownish gray.
The melanin pigment of the pulmonary wall is distributed into irregular spots which tend to coalesce at the roof of the cavity. There is no renal ridge.

The reproductive system is shown in Fig. 4C. The ovotestis is composed of about 60 diverticula, most of which are unbranched. A minutely dissected ovotestis
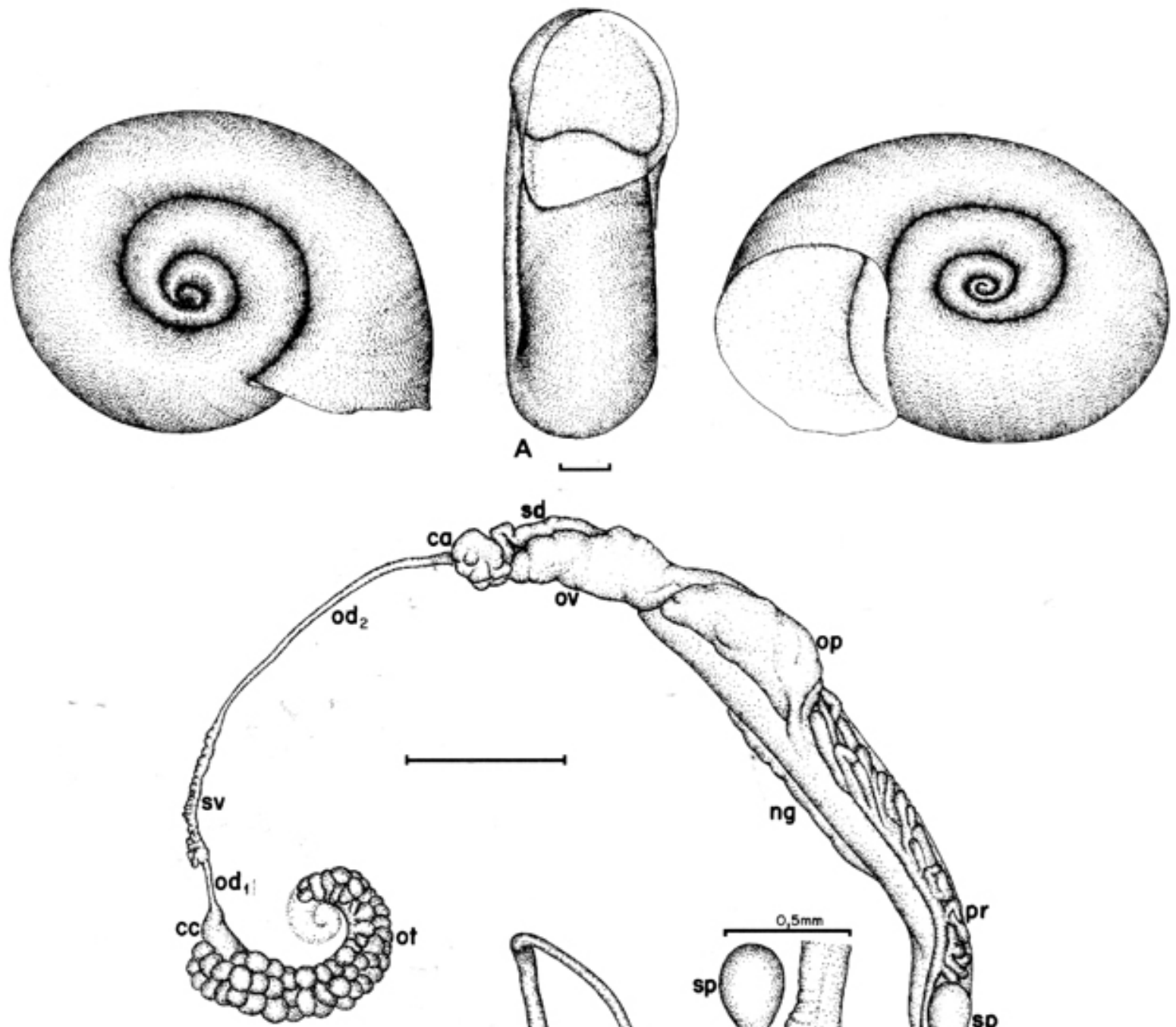

\section{ot}

B

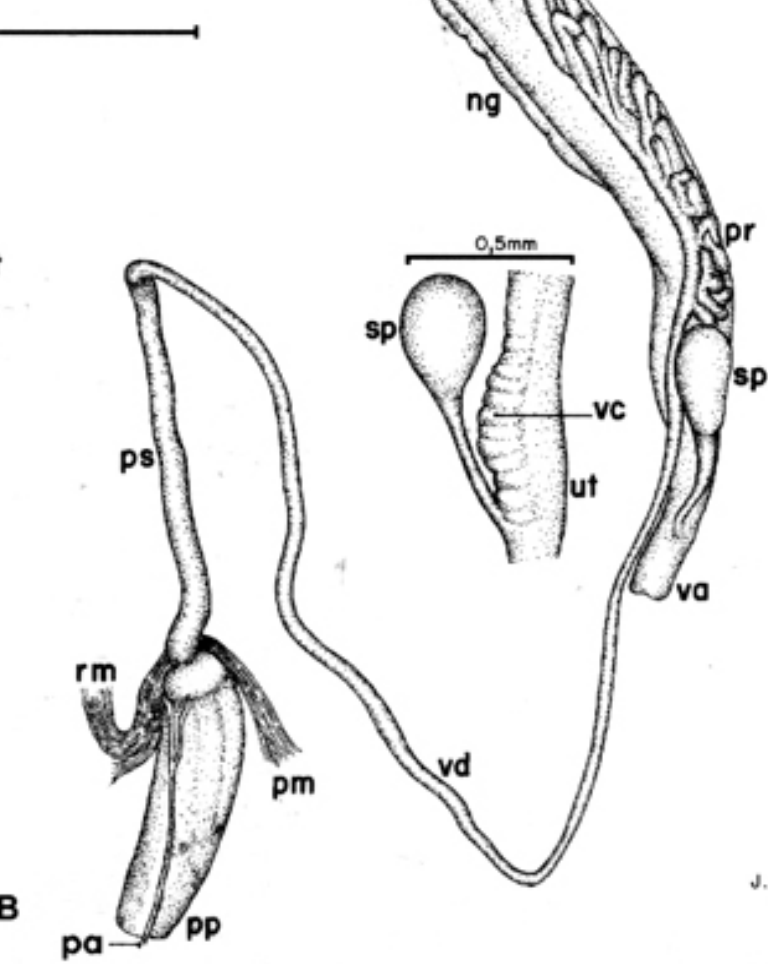

J.E.PRADO

Fig. 3: Biomphalaria kuhniana from La Isleta, Panama - A: shell; B: reproductive system. Bar $=1 \mathrm{~mm}$ (unless otherwise stated) 

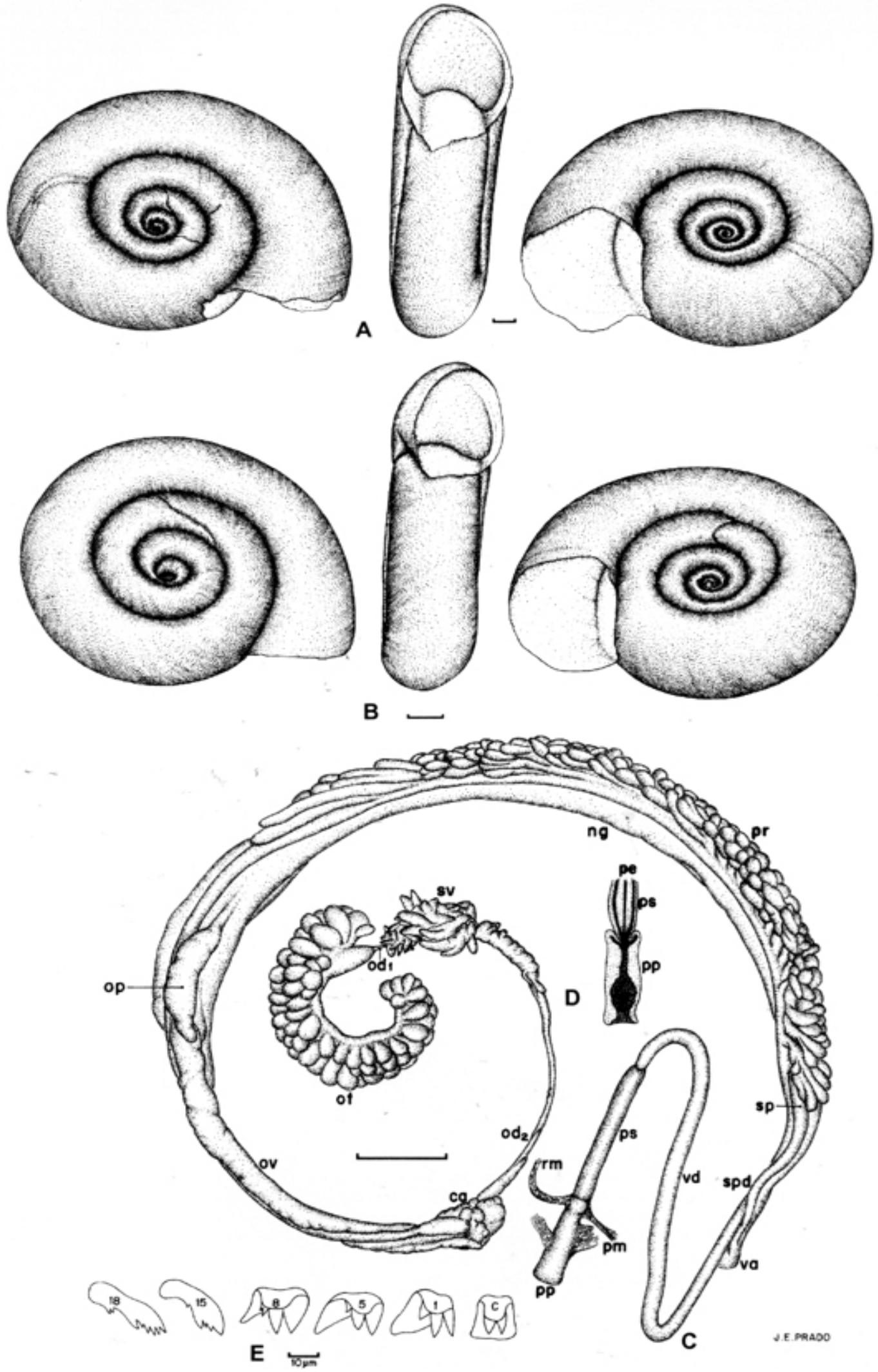

Fig. 4: Biomphalaria nicaraguana - A: type, Natural History Museum, London (1893.2.4.594); B-E: specimen from Acoyapa, near Lake Nicaragua. B: shell; C: reproductive system; D: longitudinal section of penial complex. Bar $=1 \mathrm{~mm}$. E: radular teeth; numbers indicate position in transverse row; $\mathrm{C}$ : central; 1, 5: laterals; 8: intermediate; 15, 18: marginals 
had 77 diverticula, of which 69 were simple, 6 bifurcate and 2 trifurcate. The seminal vesicle is beset with well-developed diverticula varying in shape from knoblike to fingerlike.

The oviduct is straight in larger specimens, somewhat tortuous in smaller ones, emptying into a moderately developed oviducal pouch. The nidamental gland has no taxonomically significant characteristics. The vagina is short and smooth-walled (without vaginal pouch). The spermatheca varies in shape according to the amount of its contents: club-shaped when empty, when full it shows an elongated ovoid body about as long as the duct. The caudal portion of the female duct (from the carrefour to the middle of the oviducal pouch) is about half as long as the cephalic portion (from the middle of the oviducal pouch to the vaginal opening) in adult specimens, the ratio between their lengths (caudal:cephalic) varying from 0.42 to 0.57 . The ratio between the lengths of the cephalic portion and of the penial complex varies from 2.85 to 4.76 .

The spermiduct gives off a series of 16-33 prostatic diverticula. They are short and divided into small intermingling branches which give the prostate a compact appearance, making difficult to ascertain the number of diverticula. The foremost diverticulum encircles, and sometimes overlaps, the apex of the spermathecal body. The vas deferens, chiefly its distal loop, is specially wide in comparison with the other Biomphalaria species, and about as wide as the penis sheath. The latter is uniformly cylindric, about one and a half times as long as the prepuce (penis sheath:prepuce ratio 1.53-1.80), and a little narrower. Owing to shouldering of the preputial upper end (Fig. 4D) it has a swollen appearance. The penial complex (penis sheath plus prepuce) is about 3 to 4 times shorter than the cephalic portion of the female duct (ratio cephalic portion:penial complex 2.85-4.76). The penis, about as long as the penis sheath, tapers to a point where is the outlet of the penis canal (Fig. 4D, pe). Histologically it shows an erectile tissue surrounding the penis canal and enveloped by a double muscular coat, of which the inner layer is longitudinal and the outer one circular, the whole invested by the outer epithelium. As usual with Biomphalaria, there are two main extrinsic muscles - a retractor and a protractor of the penial complex - inserted into the junction of the penis sheath with the prepuce, besides a variable number of secondary retractors and protractors attached to the preputial wall.

In one of the larger specimens the radula had 96 transverse rows of teeth, with the formula 25-1-25 (7 laterals, 6 intermediates, 12 marginals). Radular teeth are shown in Fig. 4E.

This snail resembles $B$. obstructa, from which it differs in having more protuberant whorls and forming no apertural lamellae, but conclusively in anatomic characters: absence of vaginal pouch; prostatic diverticula crowded together and hardly distinguishable; vas deferens, chiefly its distal loop, notably wider; penis sheath longer and a little narrower than the prepuce (compare with Fig. 5D). Its prostate resembles that of the extralacustrine form of Biomphalaria prona (see Paraense et al. 1992), but the latter has fewer prostatic diverticula
(7-13 against 16-33 in nicaraguana), besides having a vaginal pouch and a thinner distal loop of the vas deferens.

Voucher specimens were deposited at the Natural History Museum, London.

\section{Biomphalaria obstructa (Morelet, 1849)}

(Figs 5, 6)

Fifty-five specimens from Lake Dueñas, near San Miguel Dueñas, Sacatepéquez Department, Guatemala, 3 August 1976 (CMIOC-2307), together with $H$. trivolvis and $D$. lucidum. Largest shell: diameter $10 \mathrm{~mm}$, width 3 $\mathrm{mm}$ at aperture ( $2.5 \mathrm{~mm}$ at beginning of outer whorl); whorls 5; 22 shells with apertural lamellae. Both shell (Fig. 5A, B, C) and reproductive system (Fig. 5D) answer perfectly to the description of topotypic $B$. obstructa by Paraense (1990). One shell, $8 \mathrm{~mm}$ in diameter, with four rest marks (growth rings), indicative of growth stop (Fig. 5B), showed on dissection six apertural lamellae, not outwardly apparent, a little behind the second rest mark (Fig. 5C), formed when the shell was $6.5 \mathrm{~mm}$ in diameter.

Another sample of B. obstructa was collected from a pond at Boston village, Belize, together with $H$. trivolvis (see above): 94 specimens, largest shell $11 \mathrm{~mm}$ in diameter, whorls 5.5, with a set of apertural lamellae in the third whorl, 30 July 1976 (CMIOC-2297). Specimens about $7 \mathrm{~mm}$ in diameter (Fig. 6B) agree with Morelet's description of P. cannarum from Belize (1849: 16, no figure):

\author{
35. P. cannarum \\ Testa discoidea, superne subtiliter perforata, subtus vix \\ excavata, striata, corneofuscescens; anfr. 5-6 obtuse angulati, \\ supra semiplanulati, inferne semiteretes; apertura oblique \\ lunaris. \\ Diam. 7. - Altit. 2. \\ H. Belise, in littore Hondurasano.
}

Fig. 6A shows a type specimen of $P$. cannarum. The reproductive system of a specimen from Boston is shown in Fig. 6C.

B. obstructa was collected by Dr R Milward de Andrade at San Salvador, El Salvador, April 1963 (CMIOC-756): 18 specimens - 1 lamellate, $6.5 \mathrm{~mm}$ diameter; largest shell: diameter $12.5 \mathrm{~mm}$, width $3.5 \mathrm{~mm}$ at aperture ( $3 \mathrm{~mm}$ at beginning of outer whorl), whorls 5 .

B.obstructa is a senior synonym of Segmentina donbilli, described by Tristram (1861: 232, no figure) as follows:

31. SEGMENTINA DONBILLI, nov. spec. T. compressa, albido-cornea, tenuiter striata, superne et infra similiter umbilicata, convexiuscula, anfract. 5, lente accrescentes, rotundati: apertura obliqua, rotundata: perist. intus albo-labiatum, dentes 6 intus ostendens, quator in pariete externa duo in par. interna.

Diam. maj. 9 , min. 7 mill., alt. $2 \frac{1}{2}$ mill.

$H a b$. Lake of Dueñas.

\section{Biomphalaria straminea (Dunker, 1848)}

The occurrence of this species in the Coris river, Cartago Province, Costa Rica (Paraense et al. 1981) corresponds to its northernmost record in the American continent (12 August 1976, CMIOC-2335). 

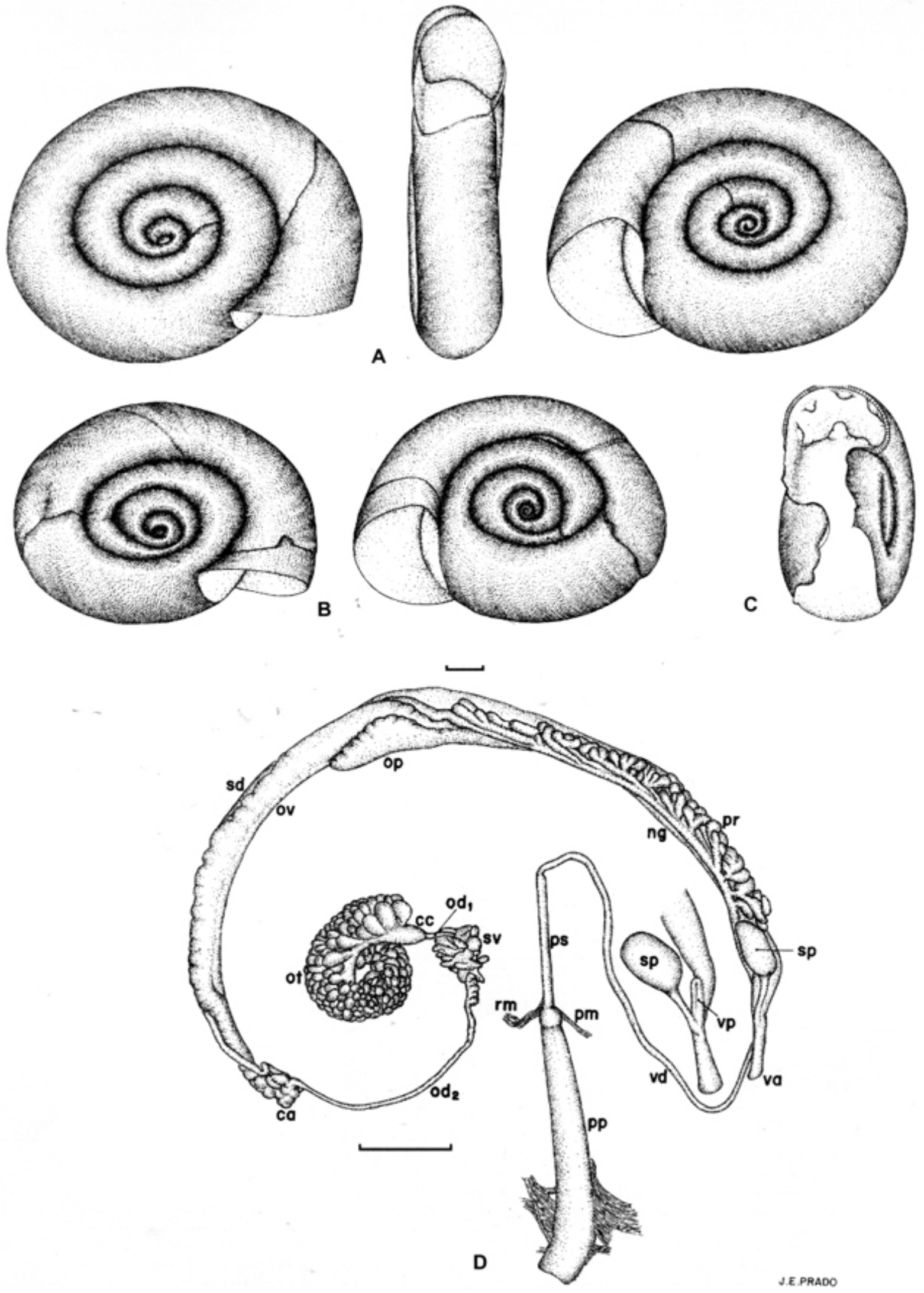

Fig. 5: Biomphalaria obstructa from Lake Dueñas, Guatemala - A: shell; B: shell with four growth rings and outwardly inapparent inner lamellae; C: specimen of Fig. B dissected to disclose inner lamellae; D: reproductive system. Bar $=1 \mathrm{~mm}$ 

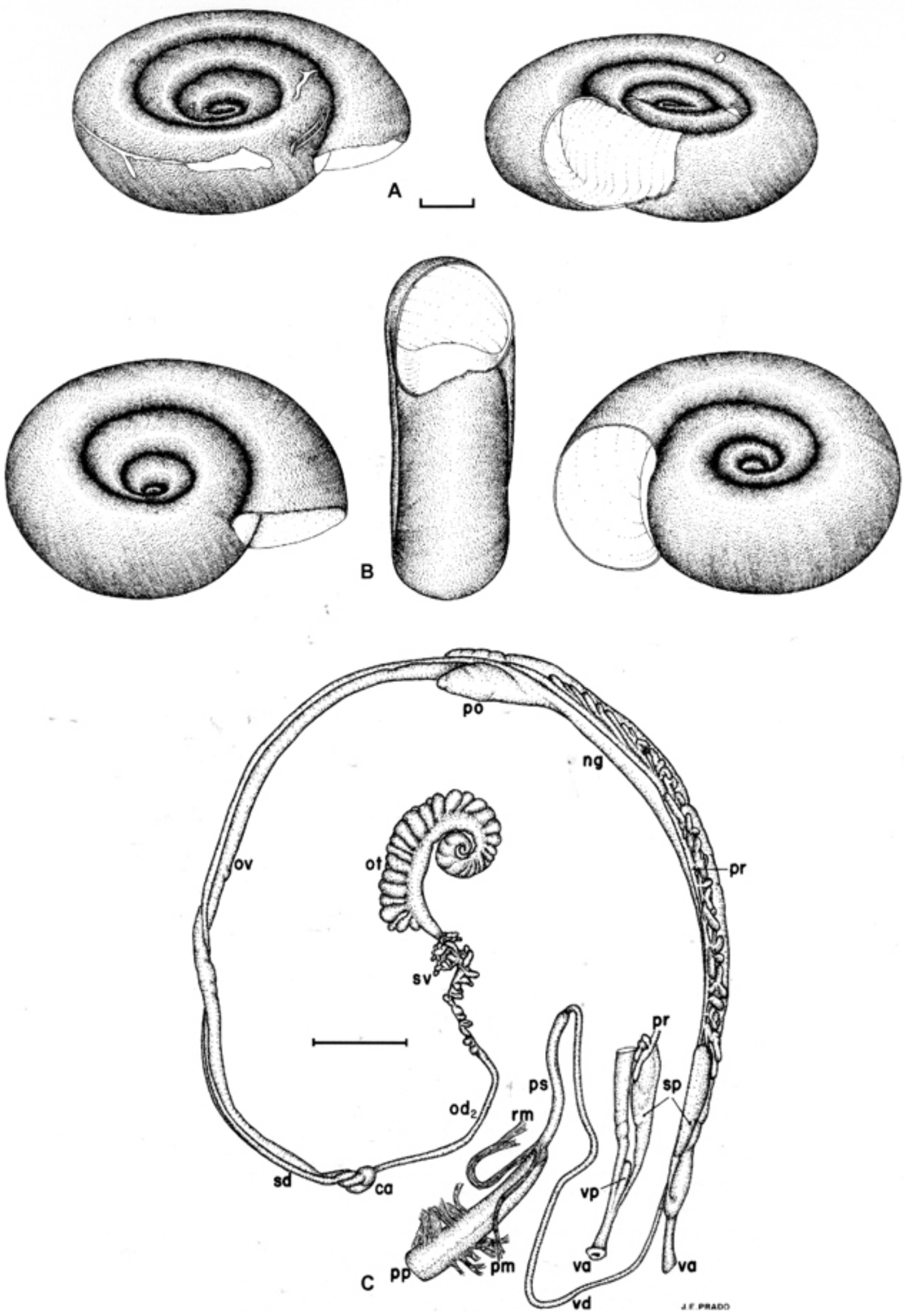

Fig. 6 - A: type specimen of Planorbis cannarum (= Biomphalaria obstructa) from Belize; Natural History Museum, London (93.2.4.6003); B: shell of Biomphalaria obstructa from Belize (CMIOC-2297); C: reproductive system of B. Bar $=1 \mathrm{~mm}$ 


\section{Biomphalaria subprona (Martens, 1899)}

Originally described from Amatitán, State of Tabasco, Mexico, this species was found by Paraense (1996b) in Lake Amatitlán, Guatemala Department, Guatemala.

\section{Genus Drepanotrema Fischer \& Crosse, 1880}

\section{Drepanotrema anatinum (Orbigny, 1835)}

(Fig. 7)

Nine specimens from a swamp by the margin of Lake Izabal at Mariscos, Izabal Department, Guatemala, 4 August 1976 (CMIOC-2310), together with D. lucidum. Largest shell: diameter $4 \mathrm{~mm}$, width $1.5 \mathrm{~mm}$ at aperture $(1.25 \mathrm{~mm}$ at beginning of outer whorl), whorls 5.5. In shell and anatomy it exactly corresponds to the description of D. anatinum by Paraense \& Deslandes (1956a).
Other samples of $D$. anatinum were collected at Belize (pond at Boston village), 30 July 1976, largest shell $2.5 \mathrm{~mm}$ (CMIOC-2301); Helado river at Taxisco, Santa Rosa Department, Guatemala, 2 August 1976, largest shell $3 \mathrm{~mm}$ (CMIOC-2302); swamp at El Prado, Izabal Department, Guatemala, 4 August 1976, largest shell 3 mm (CMIOC2313); marsh at Rivas, Rivas Department, on Lake Nicaragua, 10 August 1976, largest shell 3.5 mm (CMIOC-2324); swamp at Catalina, Guanacaste Province, Costa Rica, 12 August 1976, largest shell $4 \mathrm{~mm}$ (CMIOC-2330); and drainage ditch at the grounds of the National University, Tocumen, Panama Province, 12 June 1967, largest shell $3.5 \mathrm{~mm}$ (CMIOC-1644).

This species was described under the name of Planorbis yzabalensis by Crosse \& Fischer (1879), based on shells from Balancán (Mexico) and Lake Izabal, so that
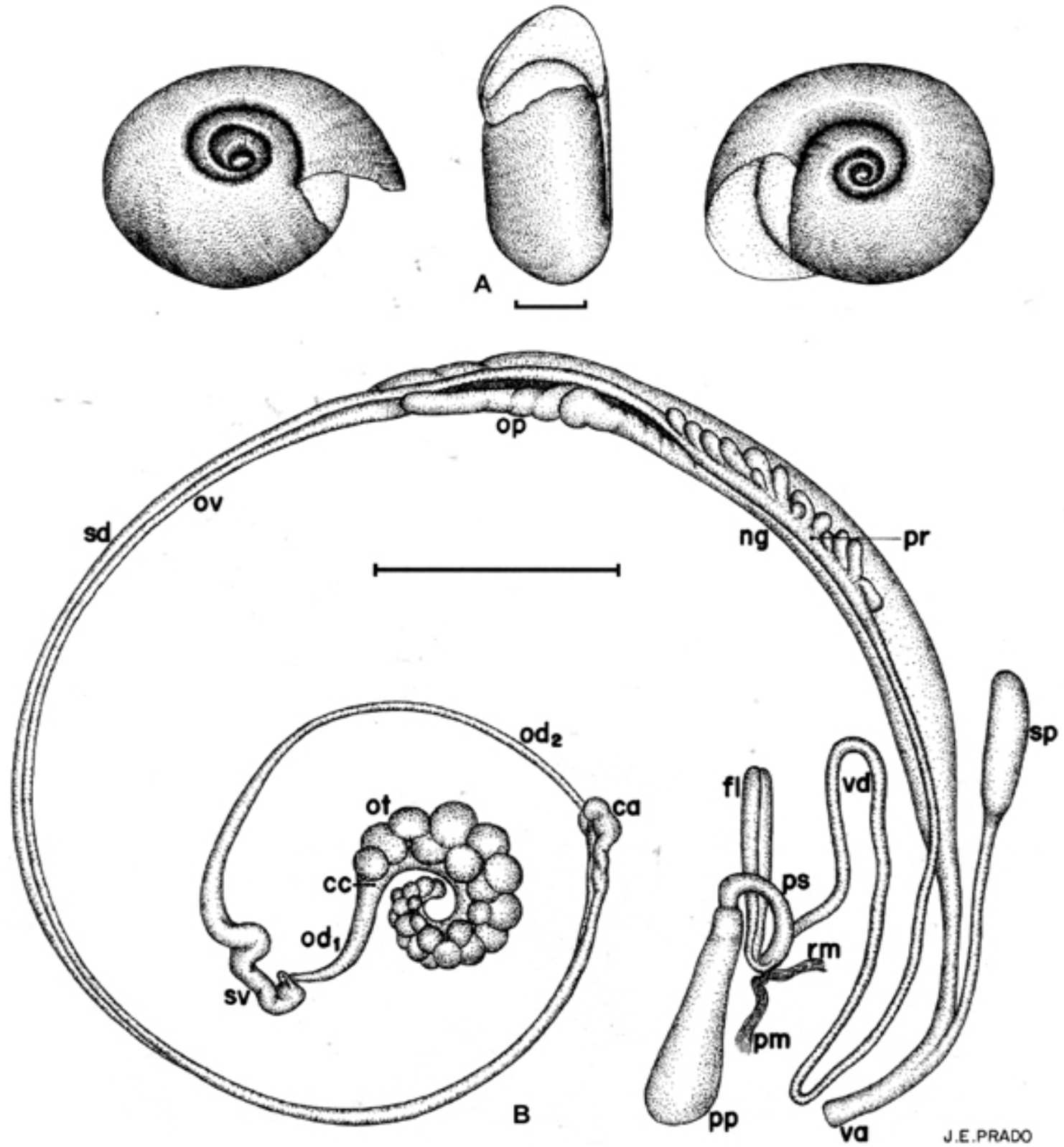

Fig. 7: Drepanotrema anatinum from Lake Izabal at Mariscos, Guatemala - A: shell; B: reproductive system. Bar $=1 \mathrm{~mm}$ 
our material is topotypic. Aguayo (1933) listed $P$. yzabalensis as a synonym of $D$. anatinum; by the way, the likeness between the two forms was stressed by Fischer \& Crosse (1880: 75-76).

\section{Drepanotrema depressissimum (Moricand, 1839)} (Fig. 8)

Two specimens from a swamp at Acoyapa, Chontales Department, Nicaragua, in syntopy with $B$. helophila and B. nicaraguana, 9 August 1976 (CMIOC-2323). Largest shell: diameter $9 \mathrm{~mm}$, width $1 \mathrm{~mm}$ at aperture $(0.75 \mathrm{~mm}$ at beginning of outer whorl), whorls 5.5. A detailed description of this species was given by Paraense and Deslandes (1957).
A single specimen of $D$. depressissimum, $5 \mathrm{~mm}$ diameter, was collected from a marsh at Rivas, on Lake Nicaragua, 10 August 1976 (CMIOC-2326); and a sample of 14 specimens was taken from a swamp at Catalina, Guanacaste Province, Costa Rica, 12 August 1976, largest shell $8 \mathrm{~mm}$ (CMIOC-2332).

After describing his Planorbis declivis (B. helophila, see above), collected near Acoyapa, Tate (1870) mentions its being accompanied by $P$. kermatoides Orbigny, 1835 . In all probability he was really dealing with $D$. depressissimum, which is present throughout South and Middle America (including the West Indies), whereas the presence of D. kermatoides outside South America needs confirmation on anatomical grounds.
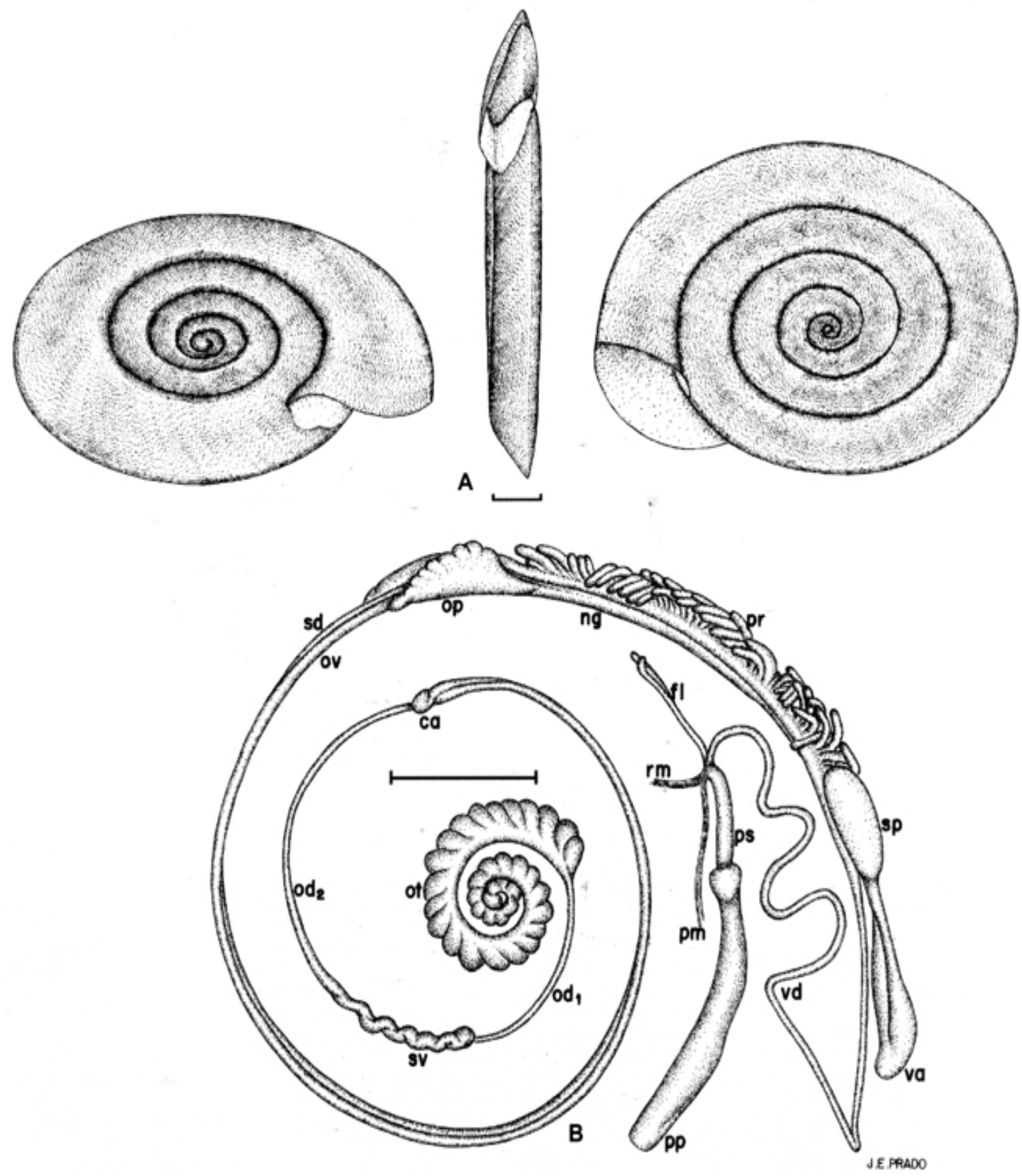

Fig. 8: Drepanotrema depressissimum from Acoyapa, near Lake Nicaragua - A: shell; B: reproductive system. Bar $=1 \mathrm{~mm}$ 
Drepanotrema lucidum (Pfeiffer, 1839)

(Fig. 9)

Twenty-six specimens from a swamp by the margin of Lake Izabal at Mariscos, Izabal Department, Guatemala, 4 August 1976 (CMIOC-2309), together with D. anatinum. Largest shell: diameter $6 \mathrm{~mm}$, width $2 \mathrm{~mm}$ at aperture $(1.5$ $\mathrm{mm}$ at beginning of outer whorl), whorls 5. Shell and anatomy as in Paraense and Deslandes' description (1956b) as D. melleum (Lutz, 1918).

Other samples of D. lucidum were collected at Belize District, from a pool beside the road to the international airport (Air Port Mile 8), together with B. helophila, 30 July 1976, largest shell 7 mm (CMIOC-2294); from marshes by the margin of Lake Nicaragua at Granada, 9 August 1976, largest shell $5 \mathrm{~mm}$ (CMIOC-2320), together with $H$. duryi and B. obstructa; and at Rivas, Nicaragua, 10 August 1976, largest shell $3.5 \mathrm{~mm}$ (CMIOC-2325), together with $D$. anatinum and $D$. depressissimum.

The occurrence of D. lucidum in Costa Rica is mentioned by Taylor (1993).
Drepanotrema surinamense (Clessin, 1884)

(Fig. 10)

Ninety-seven specimens from a highly polluted drainage ditch at Juan Diaz, about $6 \mathrm{~km}$ to the northeast of Panama City, 12 June 1967 (CMIOC-1641). Largest shell: diameter $7 \mathrm{~mm}$, width $2 \mathrm{~mm}$ at aperture (1.5 at beginning of outer whorl), whorls 5.5. For description, see Paraense and Deslandes (1960).

Additional samples were collected around Panama City, from a marsh at Las Cumbres, largest shell $6 \mathrm{~mm}$ (CMIOC-1636); and from drainage ditches at the hippodrome Presidente Remón, largest shell 7 mm (CMIOC-1640) and at Tocumen, largest shell $5 \mathrm{~mm}$ (CMIOC-1645).

D. surinamense was also found in Costa Rica, $12 \mathrm{Au}-$ gust 1976: in a marsh at Catalina, Guanacaste Province, largest shell $7.5 \mathrm{~mm}$ (CMIOC-2331), and in a ditch connected with the Coris river at Cartago, largest shell $4 \mathrm{~mm}$ (CMIOC-2337).

This species is indistinguishable by shell characters from D. lucidum (compare Figs 9 and 10), but the two

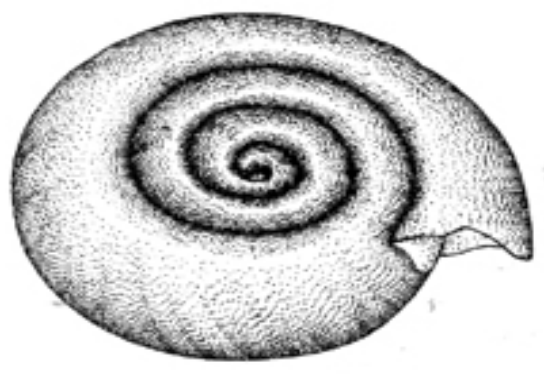

A
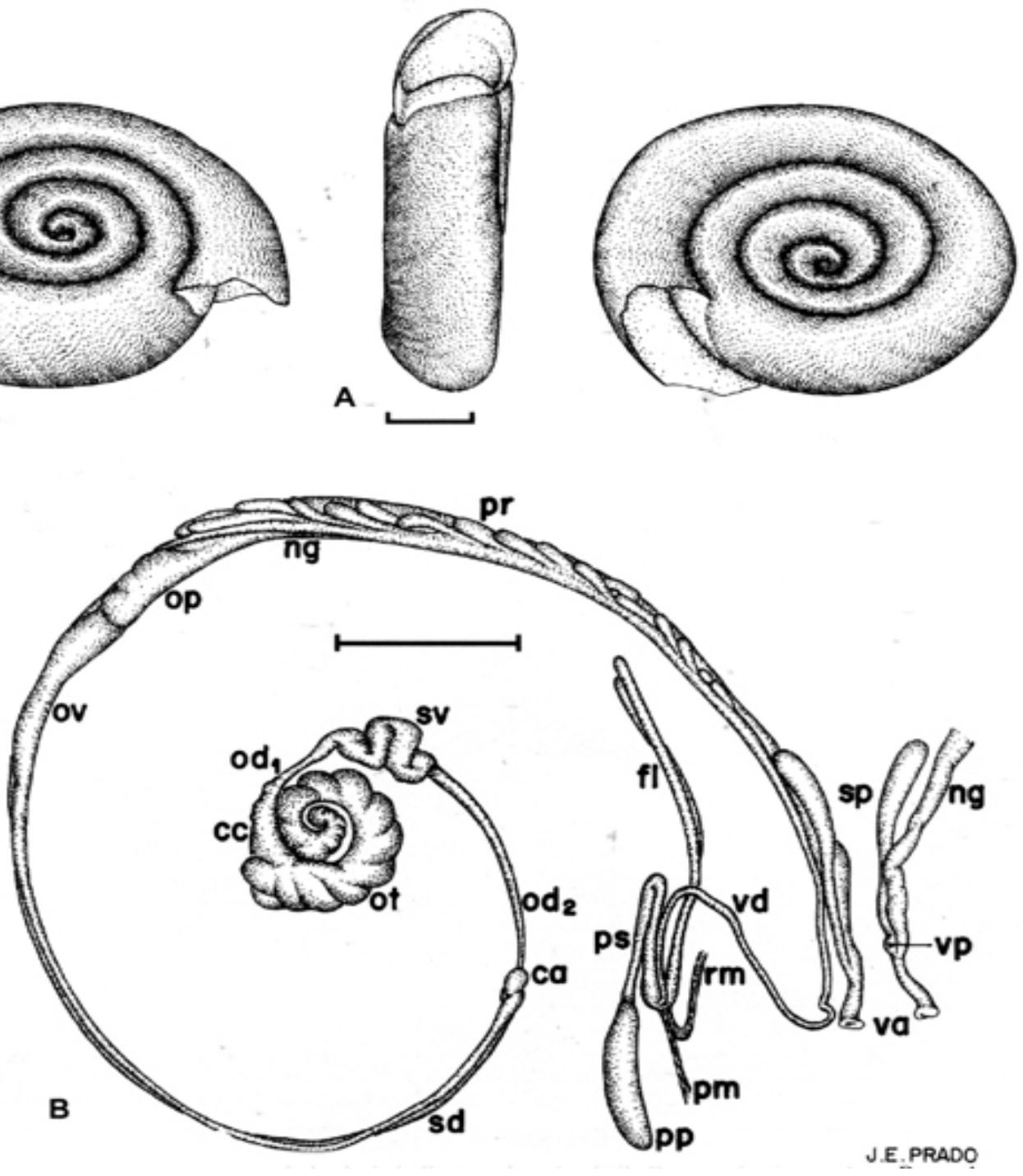

Fig. 9: Drepanotrema lucidum from Lake Izabal, Guatemala - A: shell; B: reproductive system. Bar $=1 \mathrm{~mm}$ 

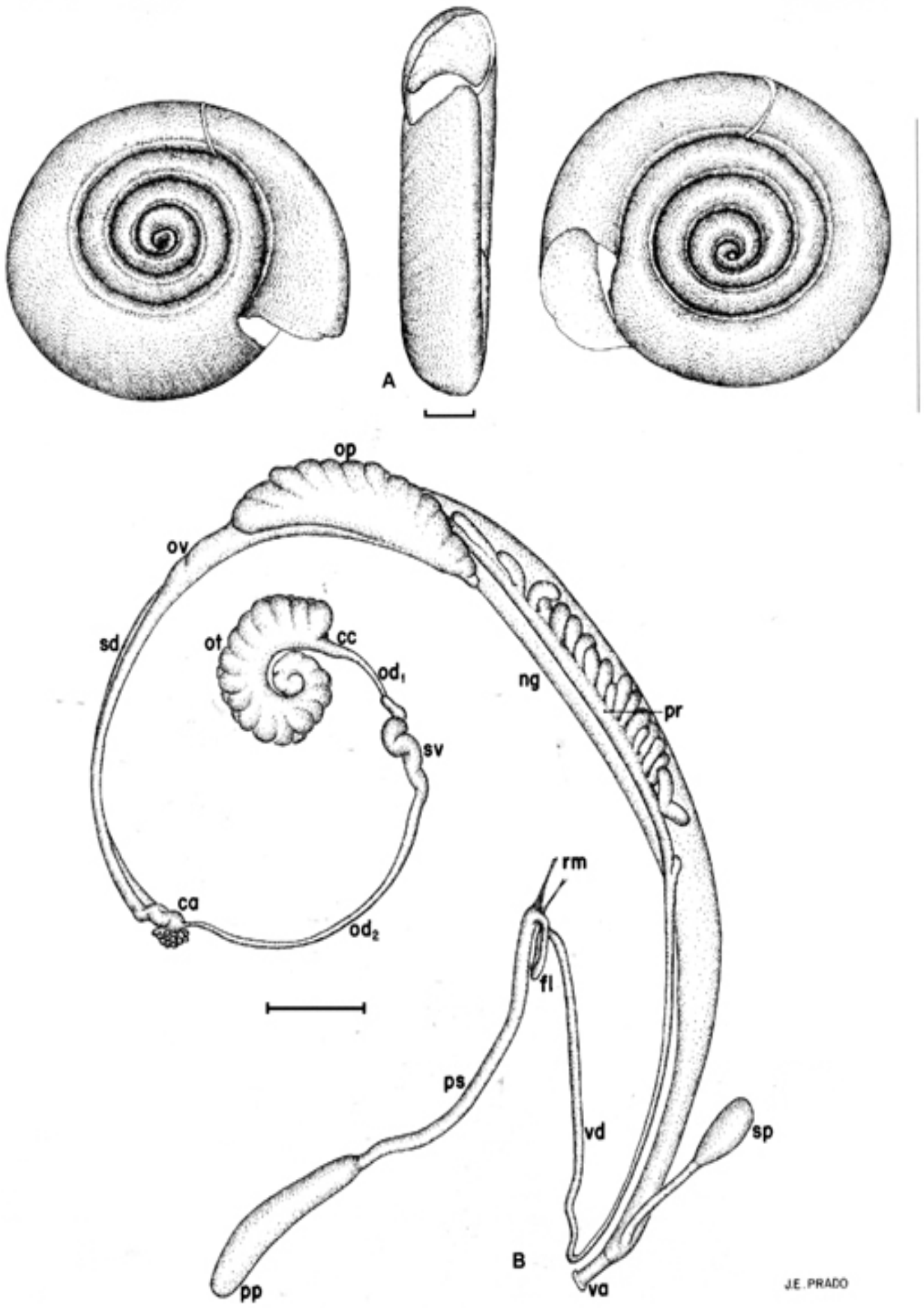

Fig. 10: Drepanotrema surinamense from Juan Diaz, Panama - A: shell; B: reproductive system. Bar $=1 \mathrm{~mm}$ 
species can be easily separated by the anatomic features.

Genus Gyraulus “Agassiz” Charpentier, 1837

Gyraulus percarinatus sp. n.

(Figs 11, 12)

(Latin per: very, extremely; carinatus: keeled)

Nineteen specimens from a drainage ditch on the grounds of the Faculty of Agronomy, Panama University at Tocumen, 12 June 1967 (CMIOC-1643). Largest shell: diameter $5 \mathrm{~mm}$, width $1.25 \mathrm{~mm}$ at aperture and beginning of outer whorl, whorls 5 .

Shell (Fig. 11A) thin, extremely flattened, honey yellowish, moderately translucent, with slowly increasing whorls plainly visible on both sides and delimited by shallow but well-marked sutures. Inner whorls widely de- pressed on both sides, a little more on the right. Body whorl widely convex, with a wide, slightly concave depression on the right at the apertural region. Growth lines slightly prominent and crossed by deeper spiral lines, so that the surface shows a finely reticulate appearance (Fig. 12B). In nondried shells the surface is beset with lines of thin hairs running over the spiral lines and more conspicuous on the periphery (Fig. 12A). Periphery strongly keeled. Aperture narrowly ogival, with a sharp peristome and a very thin callus on the parietal wall.

Cephalopedal mass diffusely brownish gray. Melanin pigment concentrated in the axis of the tentacles and arrranged in speckles throughout the pulmonary wall, accumulating on the walls of the pulmonary and renal veins. Kidney margins straight.

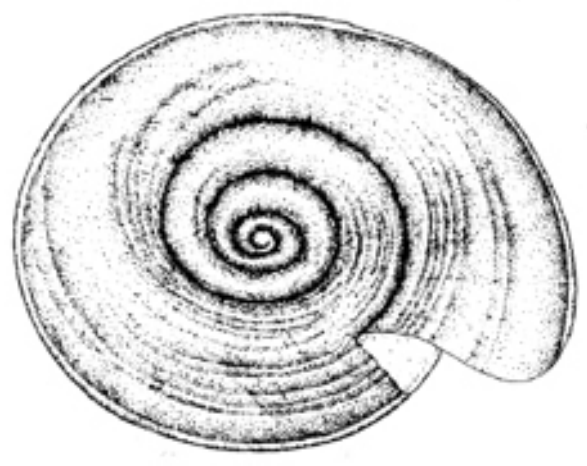

A
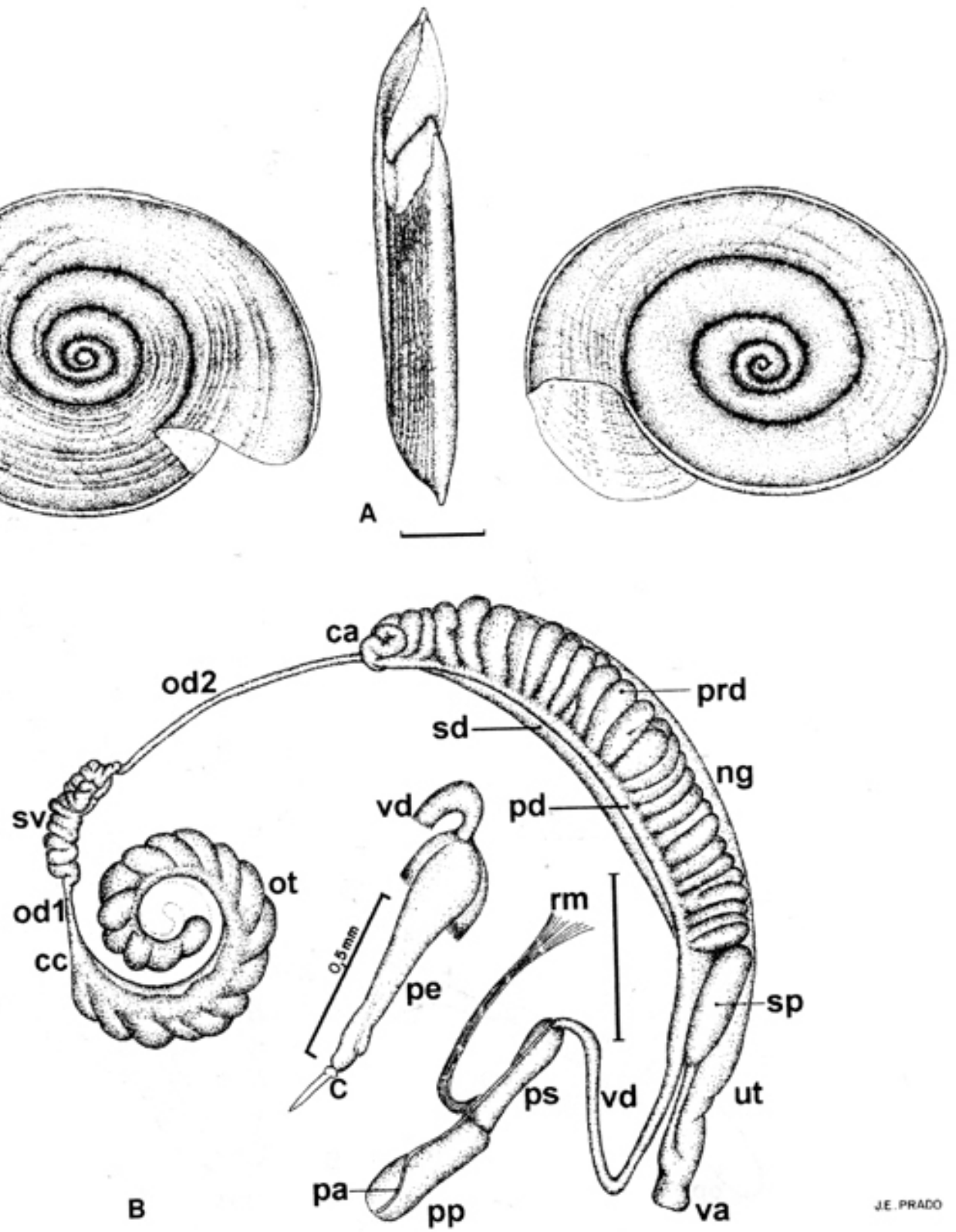

JE. PRADO

Fig. 11: Gyraulus percarinatus from Tocumen, Panama - A: shell; B: reproductive system; C: penis with stylet. Bar = $1 \mathrm{~mm}(\mathrm{except} 11 \mathrm{C})$ 
Reproductive system shown in Fig. 11B, C. Ovotestis composed of about 30 pear-shaped diverticula, usually unbranched and sometimes bifurcate (28 unbranched and 2 bifurcate in a minutely dissected ovotestis). Seminal vesicle swollen and convoluted, with some small outpocketings at the cephalic end. Oviduct short, continuing into a long flat nidamental gland. Vagina short, smooth-walled. Spermathecal body usually obovoid, varying from club-shaped to spheroidal according to the amount of its contents. Spermathecal duct about as long as the body. Spermiduct parallel to the prostatic duct, the two organs joining a little beyond the foremost prostatic diverticulum to form the vas deferens. Prostatic diver- ticula, 21 to 32 in the present sample, ovoid to oblong and unbranched (the foremost one sometimes bifurcate). Vas deferens with a descending limb running cephalad to the level of the vaginal opening, and turning back into an ascending limb about as long as the descending one (without reaching the level of the male opening as, for instance, in Biomphalaria) to open into the proximal end of the penis. Penis sheath subcylindric, a little swollen at the proximal portion, about as long as the prepuce and a little narrower. Penis proximally swollen, narrowing gradually toward its distal end, where the sperm canal opens subterminally. Penis tip furnished with a pin-like stylet. Prepuce, somewhat wider than the penis sheath, without
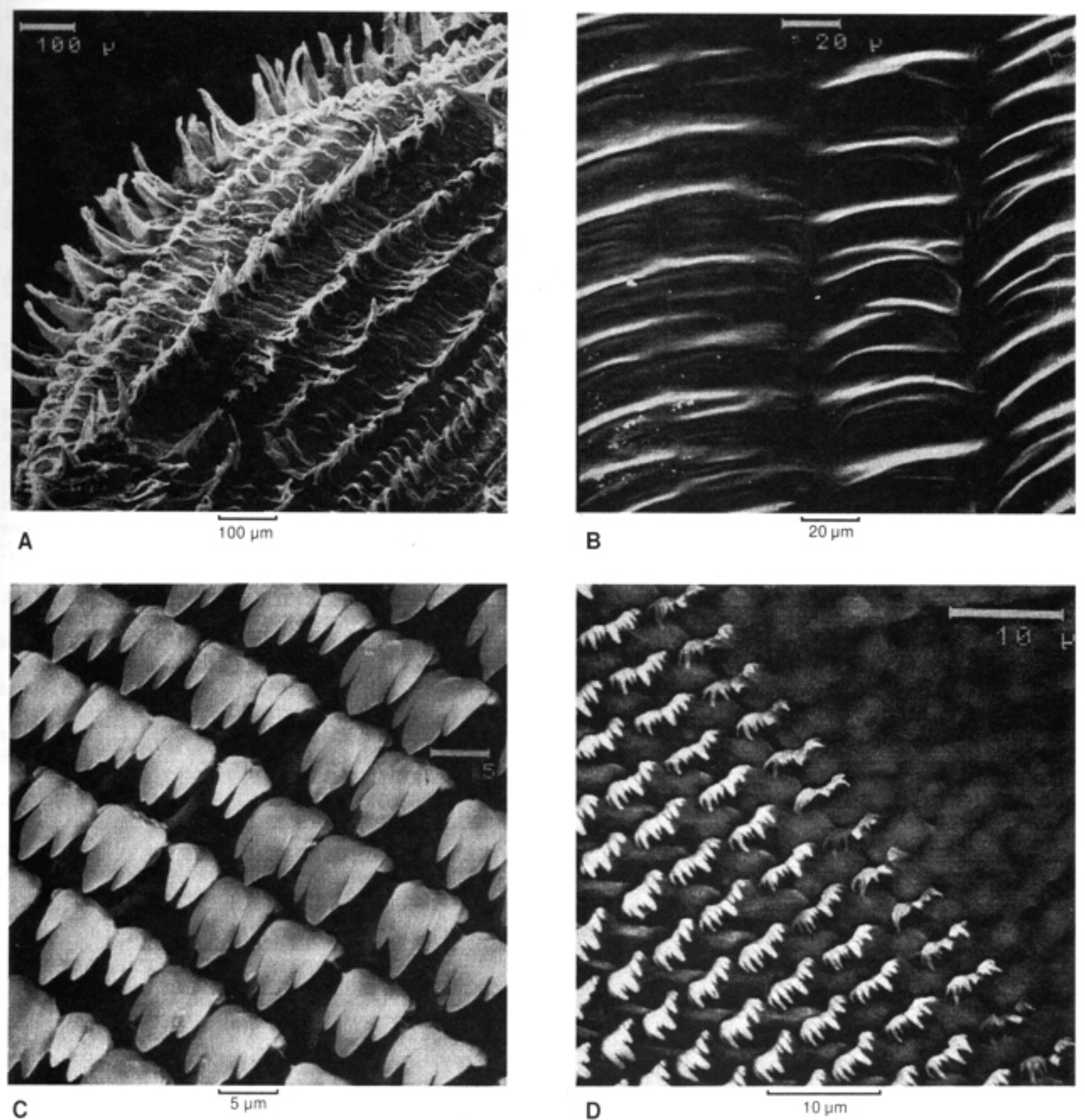

Fig. 12: Gyraulus percarinatus from Tocumen, Panama - A: shell showing hair-like projections; B: shell surface showing reticulate sculpture; C: radular teeth (central and laterals); D: radular teeth (marginals). SEM prepared by Dr Ortrud Monika Barth. 
special characteristics. A retractor muscle is attached to the cephalic end of the penis sheath. Penial complex (penis sheath plus prepuce) about one-third the length of the female duct.

Jaw fragmented with many plates, as usual in the genus.

The radula of one of the larger specimens had 124 transverse rows of teeth, with the formula 17-1-17. Radular teeth are shown in Fig. 12 C, D. Central tooth bicuspid, with a small cusp sometimes appearing high on one or both lateral sides of the tooth. Laterals tricuspid, with a longer and wider mesocone and a small cusp perceptible high on the lateral side of the ectocone. The $8^{\text {th }}$ left lateral, and the $2^{\text {nd }}$ and $3^{\text {rd }}$ right laterals, show a bifid ectocone, and the remaining laterals keep the usual tricuspid appearance. The last seven show the progressive splitting of the entocone and ectocone characteristic of marginals, in which the mesocone is flanked with 12 smaller cusps and denticles.

The shell of G. percarinatus closely resembles that of the Japanese Anisus (Gyraulus) tokyoensis Mori, 1938, differing in the absence of hairs and reticulate sculpture in the latter, whose anatomy is unknown. It also shows a high degree of similarity in shell characters to $D$. depressissimum (compare with Fig. 8A), which has a very acute periphery but a less marked reticulation and no hirsutism. It also resembles $D$. kermatoides, which is somewhat wider, much less keeled, and devoid of hairs and reticulate sculpture (for D. kermatoides see Paraense \& Deslandes, 1958).

This is the first species of Gyraulus provenly occurring in the American continent south of the United States. Another species is Planorbis (Gyraulus) boetzkesi Miller from Ecuador, so far only known by shell characters, to be defined anatomically elsewhere. Anisus (Gyraulus) lenzi Benthem Jutting, 1943 from Brazil is D. anatinum (Orbigny, 1835); and Planorbis (Gyraulus) pfeifferi Strobel, 1874 from Argentina is Antillorbis nordestensis (Lucena, 1954).

Voucher specimens were deposited at the Natural History Museum, London.

\section{ACKNOWLEDGEMENTS}

This paper is based on specimens collected during two trips supported by the Pan American Health Organization. Thanks are due to Mr Fred Naggs of the Department of Zoology, Natural History Museum, London, for the loan of specimens of Planorbis nicaraguanus and $P$. cannarum; to Dr Rodrigo Zeledón, of Instituto Costarricense de Investigación y Enseñanza en Nutrición y Salud, Costa Rica, for specimens of Helisoma duryi from Costa Rica; to Dr R Milward de Andrade for specimens of Biomphalaria helophila and B. obstructa from El Salvador; to Mr J Eduardo Prado for the preparation of figures, and to Dr Ortrud Monika Barth for the SEM micrographs.

\section{ABBREVIATIONS IN FIGURES}

ca: carrefour; cc: collecting canal of ovotestis; dpg: duct of preputial gland; fl: flagella; ng: nidamental gland; od $_{1}$ : proximal segment of ovispermiduct; od od $_{2}$ distal segment of ovispermiduct; op: oviducal pouch; ot: ovotestis; ov: oviduct; pa: penial artery; pd: prostatic duct; pe: penis; pm: protractor muscle of penial complex; pn: penial nerve; pp: prepuce; pr: prostate; prd: prostatic diverticula; ps penis sheath; pv: pulmonary vein; rm: retractor muscle of penial complex; rr: renal ridge; rt: renal tube; rv: renal vein; sd: spermiduct; sp: spermatheca; spd: spermathecal duct; sv: seminal vesicle; ur: ureter; ut: uterus; va: vagina; vc: vaginal corrugation; vd: vas deferens; vp: vaginal pouch

\section{REFERENCES}

Aguayo CG 1933. On the synonymy and distribution of Planorbis anatinus Orbigny. Nautilus 47: 64-68.

Baker FC 1941. A new species of Drepanotrema and some preoccupied planorbid names. Nautilus 54: 96-97.

Baker FC 1945. The Molluscan Family Planorbidae. University Illinois Press, Urbana, 530 pp.

Benthem Jutting WSS 1943. Über eine Sammlung nichtmariner Mollusken aus dem niederschlagsarmen Gebiete NordostBrasilien. Arch Hydrobiol 39: 458-489.

Brown AP, Pilsbry HA 1914. Fresh-water mollusks of the Oligocene of Antigua. Proc Acad Nat Sci Phila 66: 209-213.

Charpentier J 1837. Catalogue des mollusques terrestres et fluviatiles de la Suisse. Neue Denkschr Schweiz Ges Naturwiss 1: 1-2

Clessin S 1883-1886. Die Familie der Limnaeiden enthaltend die Genera Planorbis, Limnaeus, Physa und Amphipeplea. In Martini \& Chemnitz, Systematisches Conchylien-Cabinet, Ed. 2. Bauer \& Raspe, Nürnberg.

Crosse H, Fischer P 1879. Diagnoses molluscorum novorum, Guatemalae et reipublicae Mexicana incolarum. J Conchyliol 27 ( 3 e Sér., 19): 341-343.

Dunker W 1848. Diagnoses specierum novarum generis Planorbis collectionis Cumingianae. Proc Zool Soc London 16: 40-43.

Dunker W 1850. Die Familie der Limnaeiden enthaltend die Genera Planorbis, Limnaeus, Physa und Amphipeplea. In Martini \& Chemnitz, Systematisches Conchylien-Cabinet, Ed. 2. Bauer \& Raspe, Nürnberg.

Fischer P, Crosse H 1880. Études sur les mollusques terrestres et fluviatiles du Mexique et du Guatemala. In Mission Scientifique au Mexique et dans l'Amérique Centrale 2: 1-713.

Genth FA 1848. Mittheilungen an Professor Bronn gerichtet. Neu Jahrb Mineral Geogn Geol Petref: 189-199.

Haas F 1939. Malacological notes. Zool Ser, Field Mus Nat Hist 24: 93-103.

Harry HW 1962. A critical catalogue of the nominal genera and species of Neotropical Planorbidae. Malacologia 1: 33-53.

Lucena DT 1954. Tropicorbis nordestensis n sp. do Nordeste do Brasil (Nota prévia). Rev Brasil Malariol Doen Trop 6: 329-331.

Lutz A 1918. On Brasilian fresh-water shells of the genus Planorbis. Mem Inst Oswaldo Cruz 10: 45-73.

Malek EA 1969. Studies on "tropicorbid" snails (Biomphalaria: Planorbidae) from the Caribbean and Gulf of Mexico areas, including the southern United States. Malacologia 7: 183209.

Martens E 1899. Land and freshwater Mollusca. In Biologia Centrali-Americana, Taylor \& Francis, London, 706 pp.

Miller K 1879. Die Binnenmollusken von Ecuador. Malakozool Blät (Neue Folge) 1: 117-203.

Morelet A 1849. Testacea novissima insulae Cubanae et Americae centralis. Pars I, Baillière, Paris, 31 pp.

Morelet A 1851. Testacea novissima insulae Cubanae et America Centralis. Pars II, Baillière, Paris, 26 pp.

Mori S 1938. Classification of the Japanese Planorbidae. Mem Coll Sci, Kyoto Imp Univ, Ser B, 14: 279-300.

Moricand S 1839. Mémoires sur quelques coquilles fluviatiles 
et terrestres d'Amérique. Premier supplément au Mémoire sur les coquilles terrestres et fluviatiles de la Province de Bahia, en-voyées par M. Blanchet. Mém Soc Phys Hist Nat Genève 8: 139-148.

Orbigny A 1835. Synopsis terrestrium et fluviatilium molluscorum, in suo per Americam Meridionalem itinere collectorum. Mag Zool 5, Classe 5: 1-44.

Paraense WL 1976a. A natural population of Helisoma duryi in Brazil. Malacologia 15: 369-376.

Paraense WL 1976b. Helisoma trivolvis and some of its synonyms in the Neotropical region. Rev Brasil Biol 36: 187204.

Paraense WL 1988. Biomphalaria kuhniana (Clessin,1883), planorbid mollusc from South America. Mem Inst Oswaldo Cruz, 83: 1-12.

Paraense WL 1990. Biomphalaria obstructa (Morelet, 1849): a study of topotypic specimens (Mollusca: Planorbidae). Mem Inst Oswaldo Cruz 85: 391-399.

Paraense WL 1996a. Neotropical planorbid snails with apertural lamellae. I. Biomphalaria helophila (Orbigny, 1835). Mem Inst Oswaldo Cruz 91: 177-186.

Paraense WL 1996b. Biomphalaria subprona (Martens, 1899) (Gastropoda: Planorbidae). Mem Inst Oswaldo Cruz 91: 187-190.

Paraense WL,Deslandes N 1956a.The Brazilian species of Drepanotrema. I. D. anatinum (Orbigny, 1835). Rev Brasil Biol 16: 491-499.

Paraense WL, Deslandes N 1956b. The Brazilian species of Drepanotrema. II. D. melleum (Lutz, 1918). Rev Brasil Biol 16: 527-534.

Paraense WL, Deslandes N 1957. The Brazilian species of Drepanotrema. III. D. depressissimum (Moricand, 1837). Rev Brasil Biol 17: 339-344.

Paraense WL, Deslandes N 1958. The Brazilian species of Drepanotrema. VI. D. kermatoides (Orbigny, 1835). Rev Brasil Biol 18: 293-299.

Paraense WL, Deslandes N 1960. Drepanotrema surinamense, with an addendum on D. petricola (Planorbidae). Rev Brasil Biol 20: 257-263.
Paraense WL, Pointier JP, Delay B, Pernot AF, Incani RN, Balzan C, Chrosciechowski P 1992. Biomphalaria prona (Gastropoda: Planorbidae): a morphological and biochemical study. Mem Inst Oswaldo Cruz 87: 171-179.

Paraense WL, Zeledón R, Rojas G 1981. Biomphalaria straminea and other planorbid molluscs in Costa Rica. J Parasitol 67: 282-283.

Pfeiffer L 1839. Bericht über die Ergebnisse meiner Reise nach Cuba im Winter 1838-1839. Arch Naturgesch 5: 346-358.

Pilsbry HA 1920. Some Auriculidae and Planorbidae from Panama. Nautilus 30: 76-79.

Preston HB 1910. Additions to the non-marine molluscan fauna of British and German East Africa and Lake Albert Edward. Ann Mag Nat Hist, Ser 8, 6: 526-536.

Say T 1817. Conchology, 15 pp, 4 pls. In W Nicholson, 181617, American edition of the British encyclopedia, or dictionary of arts and science comprising an accurate and popular view of the present improved state of human knowledge, Samuel A. Mitchell \& Horace Ames, Philadelphia.

Simpson GG 1953. Evolution and geography, Condon Lectures, Eugene, Oregon, $63 \mathrm{pp}$.

Sowerby GB 1877. Monograph of the genus Planorbis. In LA Reeve, Conchologia Iconica 20, L. Reeve, London.

Strebel H 1873. Ein Beitrag zur Fauna mexikanischer Landund Süsswasser Conchylien. Abhand Geb Naturwiss 6: 1-69.

Strobel P 1874. Materiali per una malacostatica di terra e di acqua dolce dell'Argentina meri dionale, Nistri, Pisa, 79 pp.

Swainson W 1840. A Treatise on Malacology, London, 419 pp.

Tate R 1870 . On the land and fresh-water mollusca of Nicaragua. Am J Conchol 5: 151-162.

Taylor DW 1993. Moluscos dulceacuícolas de Costa Rica: introducción y lista preliminar. Rev Biol Trop 41: 633-635.

Tristram HB 1861. Catalogue of a collection of terrestrial and fluviatile mollusks, made by O. Salvin, Esq., M.A., F.Z.S., in Guatemala. Proc Zool Soc London: 229-233.

Wetherby AG 1879. Notes on some new or little known North American Limnaeidae. J Cincinnati Soc Nat Hist 2 : 93-100. 